\title{
Effects of Dolomitization on Porosity during Various Sedimentation-Diagenesis Processes in Carbonate Reservoirs
}

\author{
Leilei Yang ${ }^{1, *}$, Linjiao Yu ${ }^{1}$, Donghua Chen ${ }^{1}$, Keyu Liu ${ }^{2,3}$, Peng Yang ${ }^{2}$ and Xinwei Li ${ }^{1}$ \\ 1 Unconventional Petroleum Research Institute, China University of Petroleum, Beijing 102249, China; \\ 2017210109@student.cup.edu.cn (L.Y.); 2018210109@student.cup.edu.cn (D.C.); \\ 2018210513@student.cup.edu.cn (X.L.) \\ 2 School of Geosciences, China University of Petroleum (East China), Qingdao 266580, China; \\ liukeyu@upc.edu.cn (K.L.); yangp@s.upc.edu.cn (P.Y.) \\ 3 Qingdao National Laboratory for Marine Science and Technology, Qingdao 266071, China \\ * Correspondence: yangleilei@cup.edu.cn
}

Received: 2 June 2020; Accepted: 23 June 2020; Published: 25 June 2020

\begin{abstract}
Carbonate reservoirs, especially dolomite reservoirs, contain large reserves of oil and gas. The complex diagenesis is quite challenging to document the dolomite reservoirs formation and evolution mechanism. Porosity development and evolution in dolomite reservoirs primarily reflect the comprehensive effect of mineral dissolution/precipitation during dolomitization. In this study, multicomponent multiphase flow and solute transport simulation was employed to investigate dolomitization in the deep carbonate strata of the Tarim Basin, Northwest China, where active exploration is currently under way. One- and two-dimensional numerical models with various temperatures, fluid compositions and hydrodynamic characteristics were established to quantificationally study dolomitization and its effect on porosity. After determining the main control factors, detailed petrologic characteristics in the studied area were also analyzed to establish four corresponding diagenetic numerical models under different sedimentary environments. These models enabled a systematic analysis of mineral dissolution/precipitation and a quantitative recovery of porosity evolution during various sedimentation-diagenesis processes. The results allowed for a quantitative evaluation and prediction of reservoir porosity, which would provide a basis for further oil and gas exploration in deep carbonate reservoirs.
\end{abstract}

Keywords: carbonate reservoirs; sedimentation; diagenesis; dolomitization; porosity

\section{Introduction}

Carbonate reservoirs are widely distributed over the world and crucial for oil and gas exploration because of their proven reserves. However, carbonate reservoirs are usually developed with complicated crack/pores during diagenesis, which make the reservoir prediction difficult and hinder the development of oil and gas exploration [1-7] It is of great importance to understand the effect of diagenesis on the reservoir porosity evolution as it is one of the key factors affecting the reservoir quality.

The formation and evolution of reservoir porosity are the topic of carbonate reservoir research and constitute the premise for the efficiency improvement of oil and gas exploration [5,8-10]. In carbonate reservoirs, reservoir porosity evolution is mainly the result of carbonate minerals dissolution and precipitation, such as dolomitization [11-14]. Fluid-rock reactions are usually the main factor for the porosity evolution because it results in carbonates dissolving to form voids, although in some cases minerals may precipitate to fill such voids $[2,15,16]$. However, the reservoir condition 
(e.g., temperature, pressure, mineral species, formation water hydrochemistry and fluid dynamics) is crucial to the porosity evolution during the long process of diagenesis [9,17-22].

As the most important carbonate reservoir, dolomite has received wide attention [13,23-25]. With the continuous exploration and discovery of oil and gas in deep-buried dolomite formations, a string of new issues has arisen. The most important issue is how dolomitization affects the reservoir porosity during various sedimentation-diagenesis processes [26-29]. This, however, has not received notable attention as the majority of previous research works focused on qualitative testing and analysis of dolomitization, which did not provide a systematic description of carbonate minerals under different burial conditions during the whole diagenetic process [30].

In this study, the deep strata of the Tarim Basin in Northwestern China were selected to establish a number of one- and two-dimensional numerical models under various diagenetic conditions. This allowed us to analyze the effect of temperature, fluid and hydrodynamic conditions on dolomitization, and for the quantitative evaluation of the reservoir porosity change induced by dolomitization. Then, quantitative recovery of porosity evolution during various sedimentation-diagenesis processes was successfully implemented. The results allowed for a quantitative evaluation and prediction of reservoir porosity, which would provide a basis for further oil and gas exploration in deep carbonate reservoirs.

\section{Geological Background}

\subsection{Tectonic Locations}

Tarim Basin is one of the most important petroliferous basins in China, which contains thick marine carbonate deposits. The most well-developed carbonate sequence within the basin is the Cambrian-Ordovician carbonate, which is also the key intervals for oil and gas exploration [31-33]. The Ordovician carbonate reservoirs in the Shunnan (SN) area, located in the central uplift of the Tarim Basin, are selected in this study, as shown in Figure 1, based on [33,34].

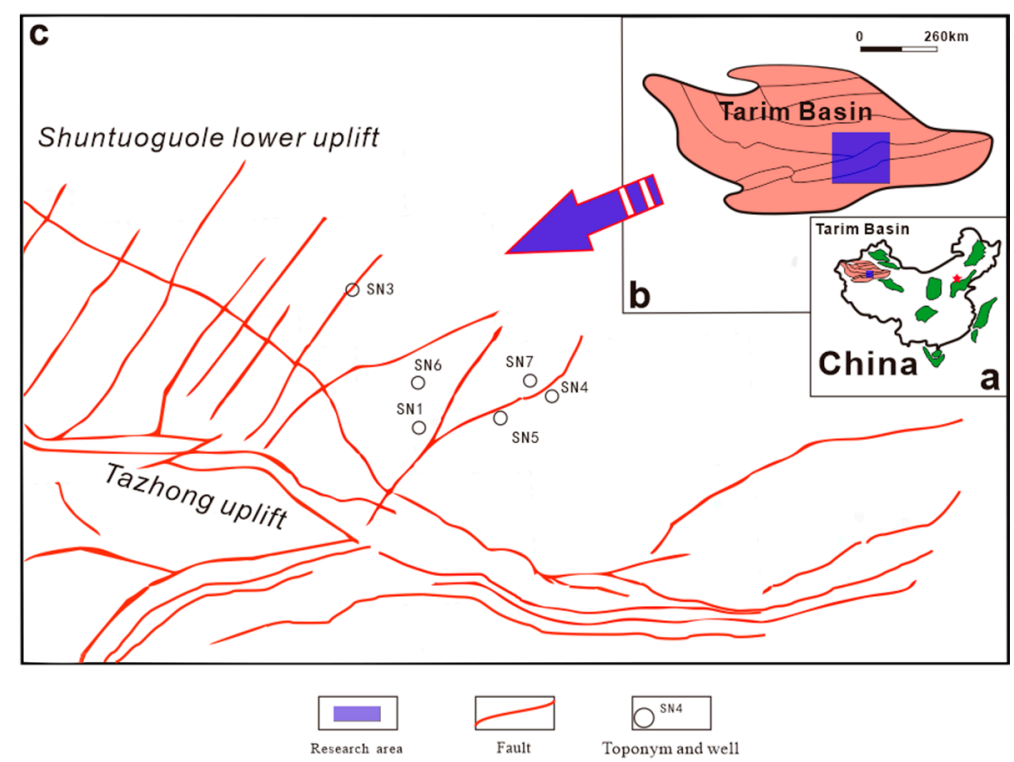

Figure 1. Tectonic locations of the Shunnan (SN) area in the northern slope of the middle Tarim Basin. (a) Location of Tarim Basin in China; (b) Location of SN in Tarim Basin; (c) Tectonic map.

\subsection{Diagenesis}

A good overview of the typical diagenesis in the studied area has been provided by various previous research, as shown in Figure $2[32,33,35,36]$ A series of core and thin sections and other petrological analyses show that the diagenesis mainly includes micritization (Figure 2a), cementation 
(Figure 2b-g), structural fractures (Figure 2e), dissolution (Figure 2f), dolomitization (Figure 2h-k), and silicification (Figure 21).
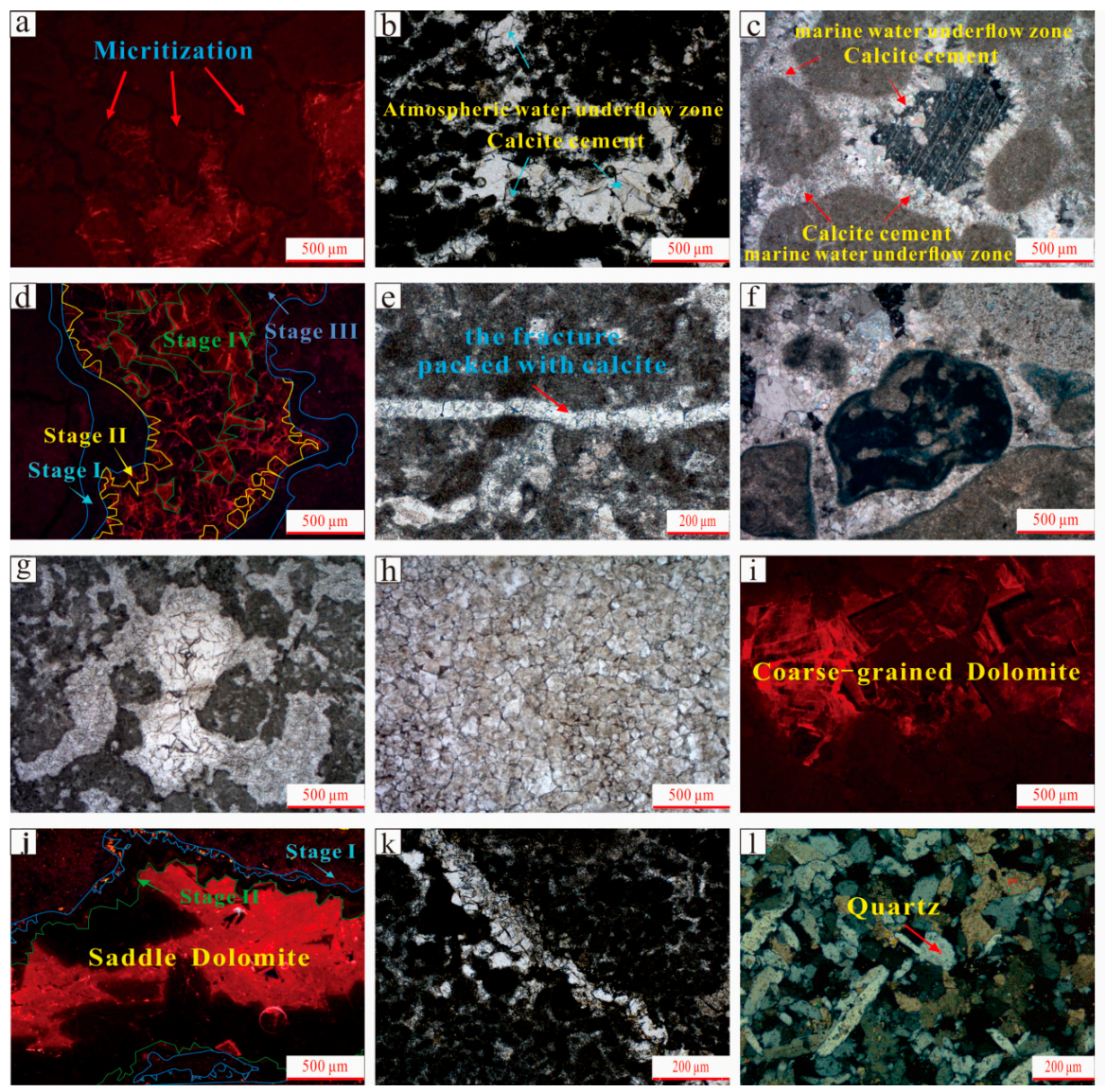

Figure 2. Typical diagenesis types of the Middle-Lower Ordovician carbonate. (a) SN6, 7325.50 m, sparry dolomitized calcarenite, small scale, cathodoluminescence; (b) SN4, $6361.13 \mathrm{~m}$, micrite calcarenite, plane polarized light; (c) SN6, $7325.50 \mathrm{~m}$, sparry dolomitized calcarenite, plane polarized light; (d) SN6, $6849.50 \mathrm{~m}$, micrite clastic limestone, cathodoluminescence; (e) SN1, $6639.70 \mathrm{~m}$, micrite calcarenite, plane polarized light; (f) SN7, $6876.40 \mathrm{~m}$, sparry calcarenite, plane polarized light; (g) SN6, $6849.50 \mathrm{~m}$, micrite calcarenite, plane polarized light; (h) SN6, $7318.50 \mathrm{~m}$, sand cutting fine crystalline dolomite, plane polarized light; (i) SN6, $7319.43 \mathrm{~m}$, fine-medium crystal residual sandy dolomites, cathodoluminescence; (j) SN7, $6534.10 \mathrm{~m}$, micrite clastic limestone, cathodoluminescence; (k) SN4, $6461.00 \mathrm{~m}$, micrite calcarenite, plane polarized light; (1) SN4, $6673.22 \mathrm{~m}$, siliceous limestone, orthogonal polarization.

The diagenetic evolution of the Ordovician reservoirs in the Tarim Basin is complex, which mainly experience submarine diagenesis, meteoric diagenesis and the deep burial diagenetic settings. It is characterized by an early weak cementation, a late compaction and pressure solution, formation of stylolite, dissolution and karstification, mixed dolomitization in the supergene stage and the rupture and formation of multiphase fractures, which are all favorable conditions for developing favorable reservoirs $[28,37]$.

Several studies suggest that the syngenetic karst and inter-stratal karst of the upper highstand system under the Middle-Lower Ordovician III interface are controlled by paleotopography and paleo-fault [38]. Such eogenetic karst reservoirs have a "quasi-layered" development model, and are filled by the subsequent formation of carbonate cement. In the late diagenetic stage, acidic hydrothermal fluids with medium-low temperature, high salinity and rich $\mathrm{SiO}_{2}$ penetrated along the fault zones, leading to hydrothermal alterations such as hydrothermal dissolution, silica replacement and quartz 
precipitation to become the main controlling factors for the formation of reservoirs. Liu [39] theorized that the Middle-Lower Ordovician dolomites in the SN area are mainly resulted from shallow burial, burial (transitional environment) and deep burial dolomitizations. The fine-grained dolomite strata formed during the burial stage have the best reservoir properties, causing grain bank metasomatism and sustained dolomitization of the mud-sized dolostone formed under a shallow burial environment [37].

The diagenetic evolution sequence of the reservoirs in the studied area is summarized in Figure 3. According to the diagenetic history, the diagenetic evolution process in the studied reservoir can be categorized into six consecutive stages, including sedimentary-parasyngenetic, parasyngenetic-shallow burial, supergene, shallow burial, middle-deep burial and the deep burial stages.

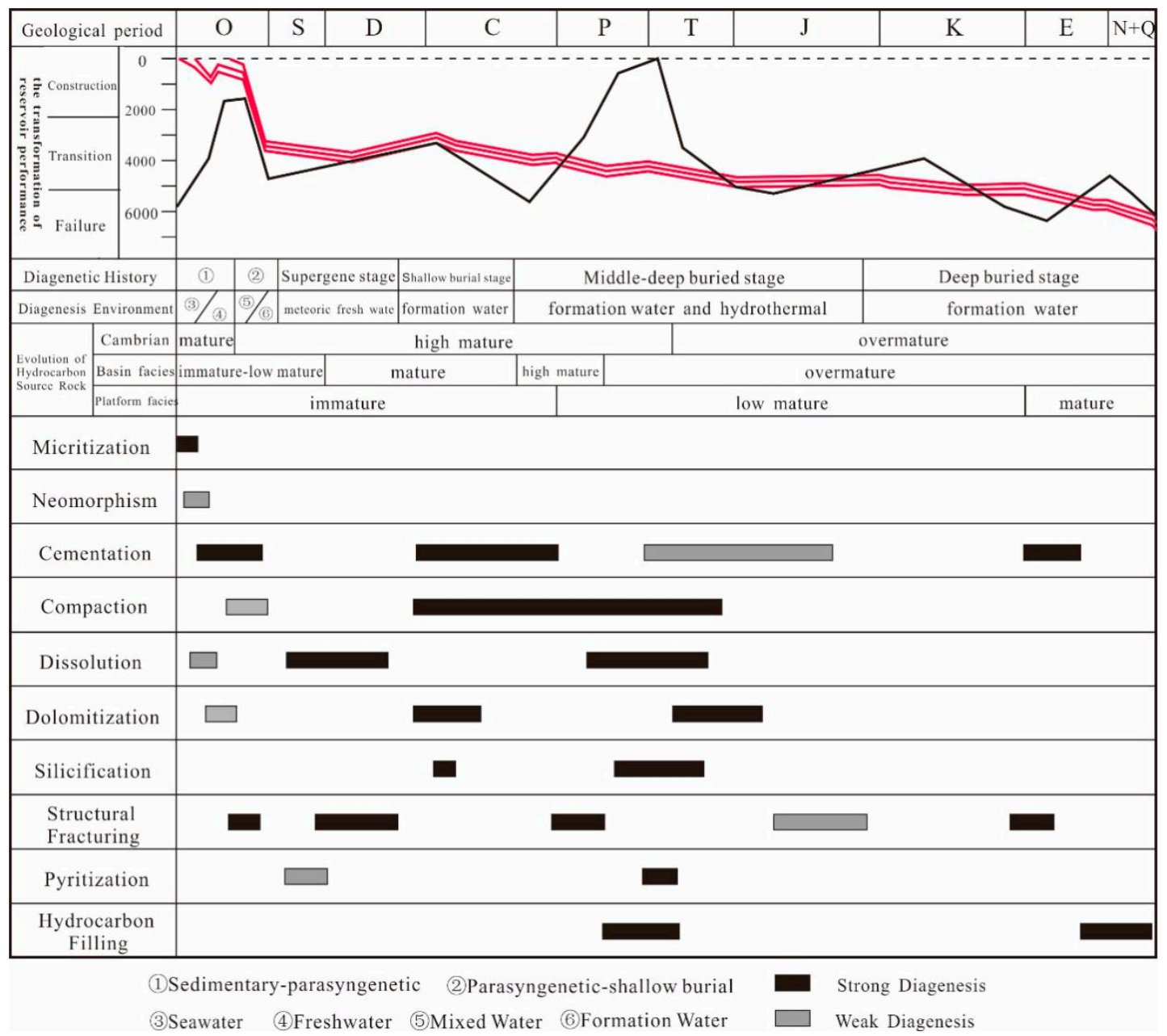

Figure 3. Diagenetic evolution of the Middle-Lower Ordovician carbonate.

\subsection{Sedimentary Environments}

The diagenetic evolution of the Ordovician carbonate rocks in the $\mathrm{SN}$ area occurred under different sedimentary environments. According to the diagenesis and petrological characteristics, the sedimentary environment can be divided into four categories: (1) marine phreatic environment in a subtidal zone, (2) meteoric fresh water and fresh water phreatic environment in a supralittoral zone, (3) seawater and freshwater interaction environment in an intertidal zone and (4) seawater evaporation environment in a shoal setting. 


\section{Model Setup}

\subsection{Model Tools}

The model tool employed is a multicomponent multiphase flow and solute transport software TOUGHREACT, which introduces reactive chemistry into the multiphase fluid and heat flow code TOUGH. The numerical method for fluid flow and chemical transport simulations is based on the integral finite difference (IFD) method for space discretization. Thermal, hydraulic and chemical fields are coupled to model fluid flow, solute transport and reactions simultaneously [40].

At present, TOUGHREACT has been widely used in diagenesis-related research, enhanced geothermal system, $\mathrm{CO}_{2}$ storage and other geological study. It can accommodate any number of chemical species present in the liquid, gas and solid phases. Several porosity-permeability models are available to calculate the reservoir porosity and permeability changed by mineral transformation in real time. Mineral dissolution and precipitation are simulated by equilibrium and kinetic equations, which are showed as follows [40].

\subsubsection{Equilibrium Mineral Dissolution/Precipitation}

The mineral saturation ratio can be expressed as

$$
\Omega_{m}=K_{m}^{-1} \prod_{j=1}^{N_{C}} c_{j}^{v_{m j}} \gamma_{j}^{v_{m j}} m=1, \ldots, N_{P}
$$

where $m$ is the equilibrium mineral index, $K_{m}$ is the corresponding equilibrium constant, $c$ is concentration, $\gamma$ is thermodynamic activity coefficient, and $N c$ is aqueous species. At equilibrium, we have

$$
S I_{m}=\log _{10} \Omega_{m}=0
$$

where $S I_{m}$ is called the mineral saturation index.

\subsubsection{Kinetic Mineral Dissolution/Precipitation}

Kinetic rates could be functions of non-basis species as well. Usually the species appearing in rate laws happen to be basis species.

$$
r_{n}=f\left(c_{1}, c_{2}, \cdots, c_{N_{C}}\right)= \pm k_{n} A_{n}\left|1-\Omega_{n}^{\theta}\right|^{\eta} n=1, \ldots, N_{q}
$$

where positive values of $r_{n}$ indicate dissolution, and negative values precipitation, $k_{n}$ is the rate constant (moles per unit mineral surface area and unit time), which is temperature dependent, $A_{n}$ is the specific reactive surface area per $\mathrm{kg} \mathrm{H}_{2} \mathrm{O}$ and $n$ is the kinetic mineral saturation ratio.

\subsection{One-Dimensional Flow}

In order to clearly distinguish and understand the influence of any single factor on mineral transformation and porosity evolution, and to avoid multi-factor interference, a simple and typical one-dimensional model was established. The total length of this horizontal direction model was $150 \mathrm{~m}$, divided into 50 equidistant grid cells. Fluid was injected from the left side at a constant rate, which promoted the flow of formation water from the left to the right.

In the Base Case, parameters were set according to the actual physical properties and chemical conditions of the carbonate reservoir studied. The initial temperature was set to $40{ }^{\circ} \mathrm{C}$ and the initial pressure was set to equal to the atmospheric pressure. The initial state of the reservoir was assumed to be homogeneous, and the initial porosity was 0.35 . At the beginning of the model run, the minerals in the formation were all calcite. The flow rate of fluid in the formation was set to $4 \mathrm{~m}$ per year, while the $\mathrm{pH}$ of the inflowing external water was 8.5 , and the $\mathrm{Mg} / \mathrm{Ca}$ ratio was 5.25. Thirteen different models, 
Cases 1-13 were set up to compare the effects of different factors on dolomitization, such as temperature, flow rate, seawater concentration, $\mathrm{Mg} / \mathrm{Ca}$ ratio, $\mathrm{pH}$ and $\mathrm{SO}_{4}{ }^{2-}$ concentration. The specific conditions of these various experiments are listed in Table 1 . The values not specified in Table 1 are shown with a dash (-) and indicate same conditions as the Base Case. Table 2 displays four seawater concentrations involved in the simulation.

Table 1. Parameters setting for one-dimensional flow models.

\begin{tabular}{|c|c|c|c|c|c|c|}
\hline Model No. & $\mathrm{T}\left({ }^{\circ} \mathrm{C}\right)$ & Flow Rate (m/yr) & Seawater Index & $\mathrm{Mg} / \mathrm{Ca}$ & $\mathrm{pH}$ & $\mathrm{SO}_{4}^{2-}(\mathrm{mmol} / \mathrm{L})$ \\
\hline Base Case & 40 & 4 & $1 \#$ & 5.25 & 8.5 & 22.208 \\
\hline Case 1 & - & & - & - & - & 222.08 \\
\hline Case 2 & - & 2 & - & - & - & - \\
\hline Case 3 & - & 8 & - & - & - & - \\
\hline Case 4 & - & - & 2\# & - & - & - \\
\hline Case 5 & - & - & 3\# & - & - & - \\
\hline Case 6 & - & - & $4 \#$ & - & - & - \\
\hline Case 7 & - & - & - & 52.5 & - & - \\
\hline Case 8 & - & - & - & 10.5 & - & - \\
\hline Case 9 & - & - & - & - & 6.5 & - \\
\hline Case 10 & - & - & - & - & 9 & - \\
\hline Case 11 & 60 & - & - & - & - & - \\
\hline Case 12 & 80 & - & - & - & - & - \\
\hline Case 13 & 100 & - & - & - & - & - \\
\hline
\end{tabular}

Table 2. Multiple seawater concentrations for one-dimensional flow models.

\begin{tabular}{ccccccccc}
\hline \multirow{2}{*}{ Seawater Index } & \multirow{2}{*}{ Saltness (ppt) } & $\mathbf{C a}^{\mathbf{2 +}}$ & $\mathbf{M g}^{\mathbf{2 +}}$ & $\mathbf{K}^{+}$ & $\mathbf{N a}^{+}$ & $\mathbf{C l}^{-}$ & $\mathbf{H C O}_{3}{ }^{-}$ & $\mathbf{S O}_{4}{ }^{2-}$ \\
\cline { 3 - 8 } & & & & $\mathbf{m m o l} / \mathbf{L}$ \\
\hline $1 \#$ & 27 & 8.075 & 42.375 & 8.051 & 368.130 & 428.310 & 1.836 & 22.208 \\
$2 \#$ & 15 & 4.475 & 23.333 & 4.436 & 202.696 & 235.775 & 1.016 & 12.219 \\
$3 \#$ & 42 & 12.750 & 66.458 & 12.641 & 577.913 & 672.620 & 2.754 & 34.854 \\
$4 \#$ & 32 & 9.625 & 50.417 & 9.564 & 437.913 & 509.380 & 2.180 & 26.417 \\
\hline
\end{tabular}

\subsection{Vertical Profile Flow}

Shallow areas, close to the surface were not water-saturated, which inevitably led to unsaturated areas to exit. As different groundwater levels must affect the hydrodynamic conditions in the reservoir, two different groundwater levels $(50 \mathrm{~m}$ and $100 \mathrm{~m})$ were set to compare their effects on the dolomitization. Except for the different groundwater levels, the simulation conditions in both models were the same.

The initial mineral in the model was calcite, and the initial water type was set as shallow formation water, with a low concentration of $\mathrm{K}^{+}, \mathrm{Ca}^{2+}, \mathrm{Na}^{+}, \mathrm{Mg}^{2+}, \mathrm{Cl}^{-}, \mathrm{SO}_{4}{ }^{2-}, \mathrm{HCO}_{3}{ }^{-}$, etc. During the simulation, external fluids were continuously injected into the reservoir from the upper side of the formation. The external fluid had the same properties as seawater with higher concentrations of $\mathrm{Ca}^{2+}$ and $\mathrm{Mg}^{2+}$.

\subsection{Diagenesis Evolution}

Based on the six successive diagenetic stages categorized in Section 2, six corresponding sub-models were established. The parameters of temperature, pressure and fluid for each diagenetic stage were taken from measured data of the reservoirs studied (Table 3).

In four different sedimentary environments models, the parameter settings were as follows: the simulated temperature and pressure was $25{ }^{\circ} \mathrm{C}$ and $0.1 \mathrm{MPa}$ respectively. The seawater component had a salinity of 35 ppt [41]. The initial mineral was calcite, and the mineral content of each sub-model was based on real-time data from the previous stage.

(1) Marine phreatic environment in the subtidal zone. Under the influence of tides, seawater leaks from the surface. The infiltration rate corresponds to the water exchange rate between seawater and formation. 
(2) Meteoric fresh water and freshwater phreatic environment in the supralittoral zone. The diagenetic process consists of two sub-processes: (1) the atmospheric freshwater leaching process, with the following parameters: infiltration rate referenced to the infiltration rate of rainfall in equatorial regions, fluid composition corresponding to the equatorial region rainwater composition. (2) The shallow layer water flow process, with the fluid defined as mixed atmospheric fresh water and formation water.

(3) Seawater evaporation environment in shoal. The infiltration rate corresponds to that at the surface.

(4) Seawater and freshwater interaction environment in intertidal zones: The diagenetic process includes two sub-processes: (1) atmospheric freshwater leaching with an infiltration rate corresponding to the annual rainfall in the equatorial region and a fluid composition referring to the rainwater component in the equatorial region. (2) Seawater infiltration process after sea level rise. The infiltration rate corresponds to the water exchange rate between seawater and formation.

Table 3. Parameters of six sub-models corresponding to different diagenetic stages.

\begin{tabular}{|c|c|c|c|c|c|c|}
\hline $\begin{array}{l}\text { Sub-Models } \\
\text { No. }\end{array}$ & Diagenesis Stage & $\begin{array}{l}\text { Diagenetic } \\
\text { Time (Ma) }\end{array}$ & $\begin{array}{c}\text { Buried } \\
\text { Depth (m) }\end{array}$ & $\begin{array}{c}\text { Temperature } \\
\left({ }^{\circ} \mathrm{C}\right)\end{array}$ & $\begin{array}{c}\text { Fluid } \\
\text { Composition }\end{array}$ & $\begin{array}{c}\text { Mineral } \\
\text { Composition }\end{array}$ \\
\hline $1 \#$ & $\begin{array}{l}\text { Sedimentary-parasyngenetic } \\
\text { stage }\end{array}$ & $488-465$ & $0-100$ & 25 & $\begin{array}{l}\text { seawater, meteoric } \\
\text { fresh water }\end{array}$ & $\begin{array}{l}\text { micritization, } \\
\text { calcite cement }\end{array}$ \\
\hline $2 \#$ & $\begin{array}{l}\text { Parasyngenetic-shallow } \\
\text { burial stage }\end{array}$ & $465-460$ & $50-600$ & $25-40$ & $\begin{array}{l}\text { mixed water, } \\
\text { formation water }\end{array}$ & calcite cement \\
\hline $3 \#$ & Supergene stage & $460-455$ & $0-50$ & 25 & $\begin{array}{l}\text { meteoric fresh } \\
\text { water }\end{array}$ & calcite cement \\
\hline $4 \#$ & Shallow burial stage & $455-445$ & $50-600$ & $25-40$ & formation water & calcite cement \\
\hline $5 \#$ & Middle-deep buried stage & $445-252$ & $600-4600$ & $40-120$ & $\begin{array}{l}\text { formation water, } \\
\text { hydrothermal }\end{array}$ & $\begin{array}{l}\text { calcite, dolomite, } \\
\text { siliceous cement }\end{array}$ \\
\hline $6 \#$ & Deep buried stage & $252-0$ & $4600-7000$ & $120-165$ & formation water & calcite cement \\
\hline
\end{tabular}

\section{Results}

The main chemical reactions occurring in carbonate reservoirs are shown in reaction formulas (4)-(6). With the intrusion of external fluid, the original balance was disrupted, which made the calcite dissolve and release $\mathrm{Ca}^{2+}$ and $\mathrm{CO}_{3}{ }^{2-}$, which could then combine with $\mathrm{Mg}^{2+}$ in the external fluid to generate dolomite. The released $\mathrm{Ca}^{2+}$ could combine with $\mathrm{SO}_{4}{ }^{2-}$ to generate gypsum under certain conditions in this process.

$$
\begin{gathered}
\mathrm{CaCO}_{3} \rightarrow \mathrm{Ca}^{2+}+\mathrm{CO}_{3}^{2-} \\
2 \mathrm{CaCO}_{3}+\mathrm{Mg}^{2+} \rightarrow \mathrm{CaMg}\left(\mathrm{CO}_{3}\right)_{2}+\mathrm{Ca}^{2+} \\
\mathrm{Ca}^{2+}+\mathrm{SO}_{4}{ }^{2-} \rightarrow \mathrm{CaSO}_{4}
\end{gathered}
$$

\subsection{One-Dimensional Flow}

Relative content of calcite, dolomite and porosity evolution in the Base Case are shown in Figure 4. At the initial model ( $\mathrm{T}=0 \mathrm{My}$ ), the relative content of calcite, dolomite and gypsum were 0.65 , 0.00 and 0.00 , respectively. Calcite nearer the injection point (left of the model, $X=0 \mathrm{~m}$ ) dissolved first and gradually transformed into dolomite. All calcite was converted to dolomite within $15 \mathrm{~m}$ from the injection point at $0.5 \mathrm{My}$, while the content of calcite was 0.00 and the content of dolomite was close to 0.60 within $60 \mathrm{~m}$ from the injection point at $1 \mathrm{My}$. The porosity within $15 \mathrm{~m}$ from the injection point was up to about $44 \%$ at $0.5 \mathrm{My}$ and reached its maximum from the injection point within $60 \mathrm{~m}$ at $1 \mathrm{My}$. 

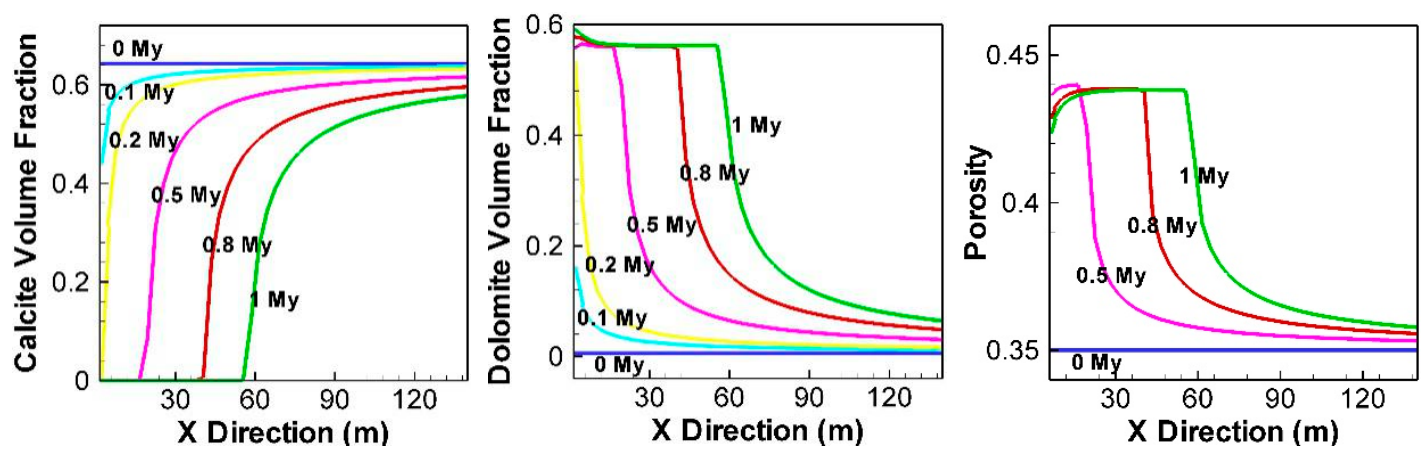

Figure 4. Calcite and dolomite content and porosity evolution (Base Case).

In Case 1, the concentration of $\mathrm{SO}_{4}{ }^{2-}$ in the injected water was 10 times higher than that in the Base Case. Results in Figure 5 show that the calcite nearest to the injection point dissolved first and gradually transformed to dolomite. No calcite was found within $70 \mathrm{~m}$ of the injection point after $1 \mathrm{My}$, when the dolomite content was up to 0.55. During the transformation of calcite to dolomite,

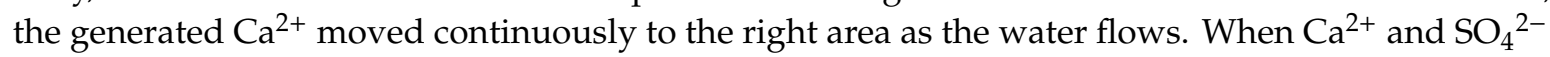
concentrations in the system reached the conditions for gypsum precipitation, gypsum was formed. As the curve of gypsum content shows, the content reached the highest value at a distance of $10 \mathrm{~m}$ from the injection point after 0.5 My. With continuous injection of external fluids, more and more gypsum precipitated. The gypsum content was close to 0.4 between 20 and $80 \mathrm{~m}$ from the injection point after $1 \mathrm{My}$. The porosity increased to about 0.45 within $20 \mathrm{~m}$ of the injection point after $0.5 \mathrm{My}$, whereas it decreased to about 0.05 between 20 and $80 \mathrm{~m}$ from the injection point after $1 \mathrm{My}$.
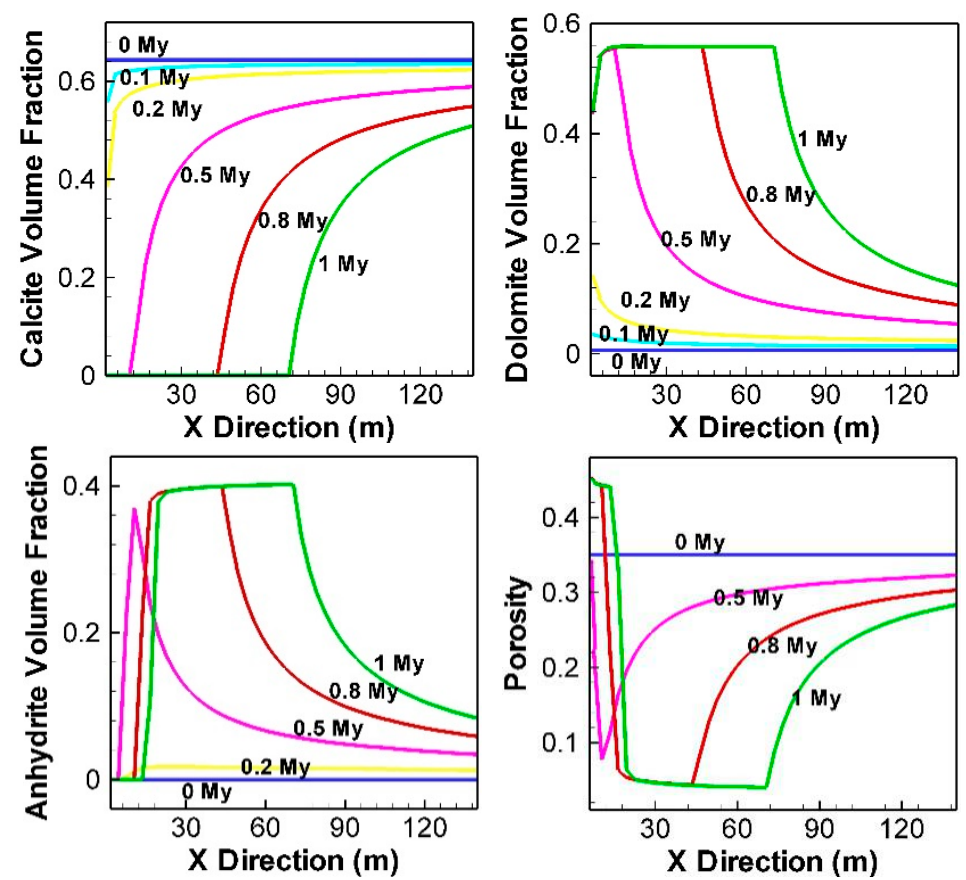

Figure 5. Calcite and dolomite content and porosity evolution (Case 1).

The change of porosity in different models is shown in Figure 6. The main difference between Case 2, Case 3 and the Base Case was hydrodynamic conditions. The fluid velocity in Base Case was $4 \mathrm{~m} / \mathrm{yr}$, while that of Case 2 and Case 3 was $2 \mathrm{~m} / \mathrm{yr}$ and $8 \mathrm{~m} / \mathrm{yr}$, respectively. In Case 2, the porosity exhibited a significant increase only within $5 \mathrm{~m}$ of the injection point after $0.5 \mathrm{My}$. It took $0.8 \mathrm{My}$ for the porosity to increase to about $44 \%$ in the range of $20 \mathrm{~m}$ from the injection point. However, in Case 3, 
the range where the porosity increased to $44 \%$ was close to $40 \mathrm{~m}$ from the injection point after $0.5 \mathrm{My}$ and became nearly $90 \mathrm{~m}$ after $0.8 \mathrm{My}$.
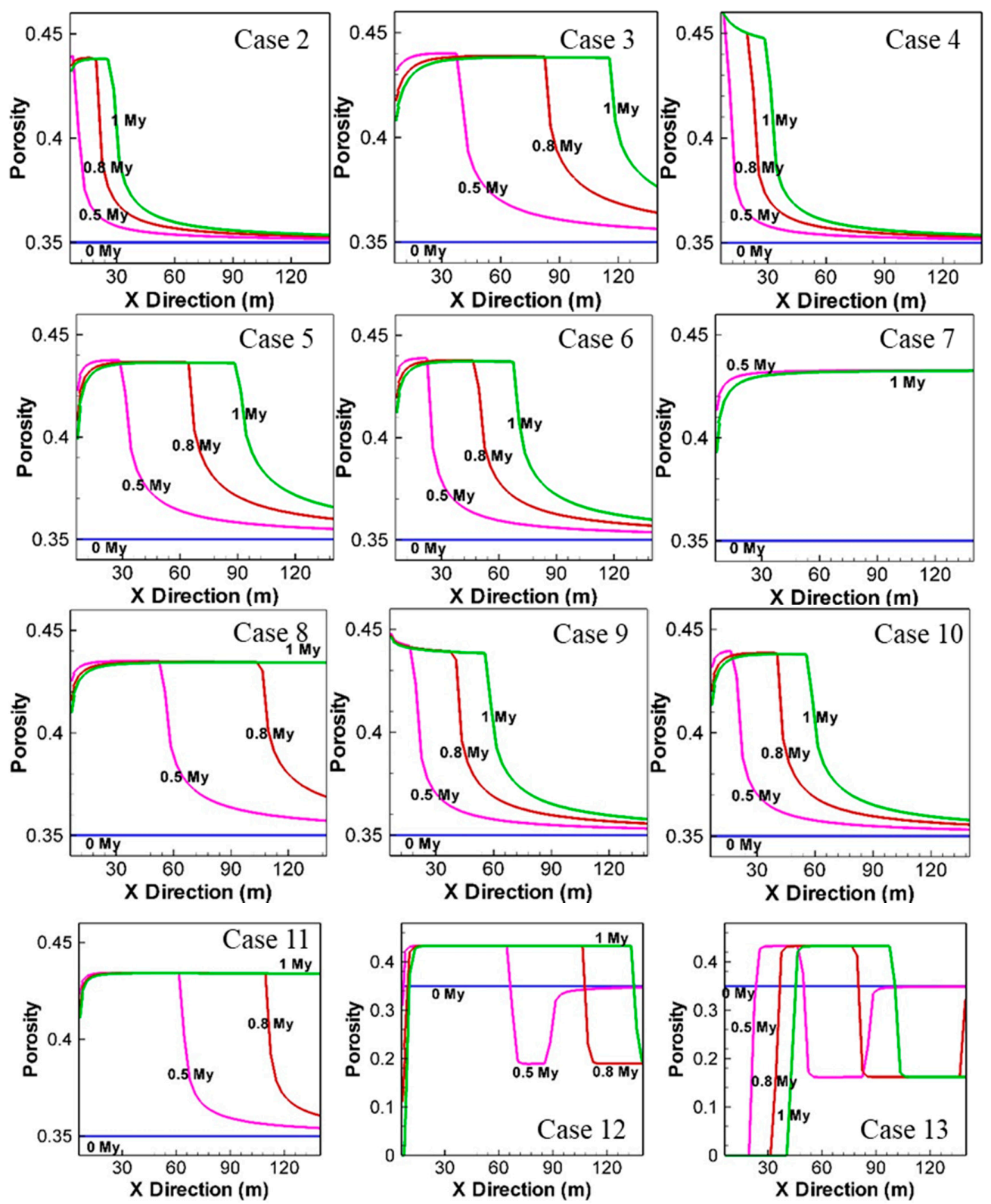

Figure 6. Porosity evolution in each model (Case 2-Case 13).

The difference between Case 4, Case 5, Case 6 and the Base Case was the injected seawater. In the Base Case, Seawater 1\# was injected, while Seawater 2\#, 3\# and 4\# were injected to Case 4, Case 5 and Case 6, respectively (Table 2). The salinities of the four types of seawater were $27 \mathrm{ppt}, 15 \mathrm{ppt}$, $32 \mathrm{ppt}$ and $42 \mathrm{ppt}$, respectively. The porosity in Case 4 was seen to increase significantly and reached a maximum of $46 \%$. The porosity higher than 0.44 at 1 My was within $30 \mathrm{~m}$ in Case 4 , while within $90 \mathrm{~m}$ and $75 \mathrm{~m}$ in Case 5 and Case 6, respectively.

The difference between Case 7, Case 8 and the Base Case was the $\mathrm{Mg} / \mathrm{Ca}$ ratio in the injected fluid. The $\mathrm{Mg} / \mathrm{Ca}$ ratio in the Base Case was 5.25, while that in Case 7 and Case 8 were 10 times and 2 times that of the Base Case. The porosity in the whole simulation range increased to more than 0.4 after $0.5 \mathrm{My}$ in Case 7 while the range was only about $50 \mathrm{~m}$ in Case 8. 
Case 9 and Case 10 differed from the Base Case in $\mathrm{pH}$ values of the injected fluid, which was 8.5 in the Base Case, against 6.5 and 9 for Case 9 and Case 10, respectively. Within $20 \mathrm{~m}$ of the injection point, the porosity in Case 9 was $44 \%$ at the injection point, whereas $41 \%$ in Case 10 .

Case 11, Case 12 and Case 13 differed from the Base Case with regards to the reservoir temperature, which was $40^{\circ} \mathrm{C}$ for the Base Case, against $60{ }^{\circ} \mathrm{C}, 80^{\circ} \mathrm{C}$ and $100^{\circ} \mathrm{C}$, for Cases 11,12 and 13 , respectively. These porosity evolution curves were largely different.

\subsection{Vertical Profile Flow}

The calcite and dolomite content at three key times for groundwater levels of $100 \mathrm{~m}$ and $50 \mathrm{~m}$ are shown in Figure 7, respectively. Regardless of the level of the groundwater, the external fluid first infiltrated into the saturated zone, after which it infiltrated into the reservoir from the surface, initiating a reaction. The reaction was enhanced at the interface between the unsaturated and the saturated zone. In the unsaturated zone, the reaction was gradually developed in the fluid flow path as a result of the accumulation of ions. For a groundwater level of $100 \mathrm{~m}$, the reaction extended to more than $200 \mathrm{~m}$ in the horizontal direction, while for a groundwater level of $50 \mathrm{~m}$, the reaction expanded to $100 \mathrm{~m}$ in the horizontal direction after $0.2 \mathrm{My}$.
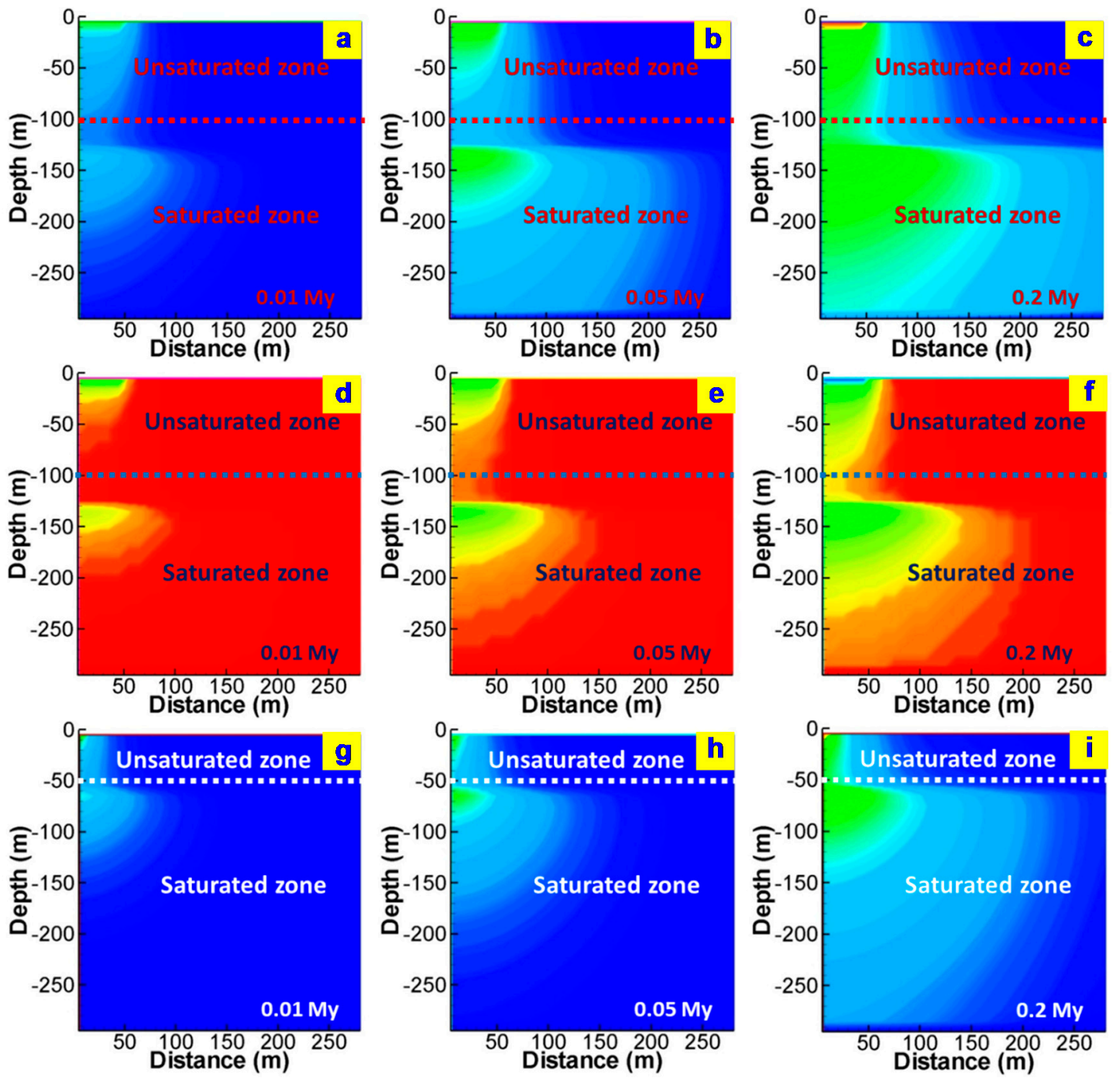

Figure 7. Calcite and dolomite content distribution after $0.01 \mathrm{My}, 0.05 \mathrm{My}$ and $0.2 \mathrm{My}$. (a-c) Calcite with groundwater level of $100 \mathrm{~m}$; (d-f) Dolomite with groundwater level of $100 \mathrm{~m}$; (g-i) Calcite with groundwater level of $50 \mathrm{~m}$. 


\subsection{Diagenetic Evolution}

\subsubsection{Marine Phreatic Environment in the Subtidal Zone}

Porosity evolution under marine phreatic environment is shown in Figure 8. Strong seawater cementation resulted in a calcite cement content of $5.1 \%$ during the sedimentary-parasyngenetic stage. During the parasyngenetic-shallow burial stage, seawater with high concentration of $\mathrm{Ca}^{2+}$ and $\mathrm{Mg}^{2+}$ was filled, which led to a strong cementation and to a drop of porosity to $20 \%$. Dissolution occurred with the development of numerous secondary pores during the supergene stage. During the shallow burial stage, a large amount of dolomite and calcite precipitated, which decreased porosity to $18 \%$. As a considerable amount of calcite was replaced by dolomite, the porosity decreased to $4.8 \%$ during the middle-deep burial stage. Finally, the porosity decreased to $1.6 \%$ because of calcite cementation in the deep burial stage.
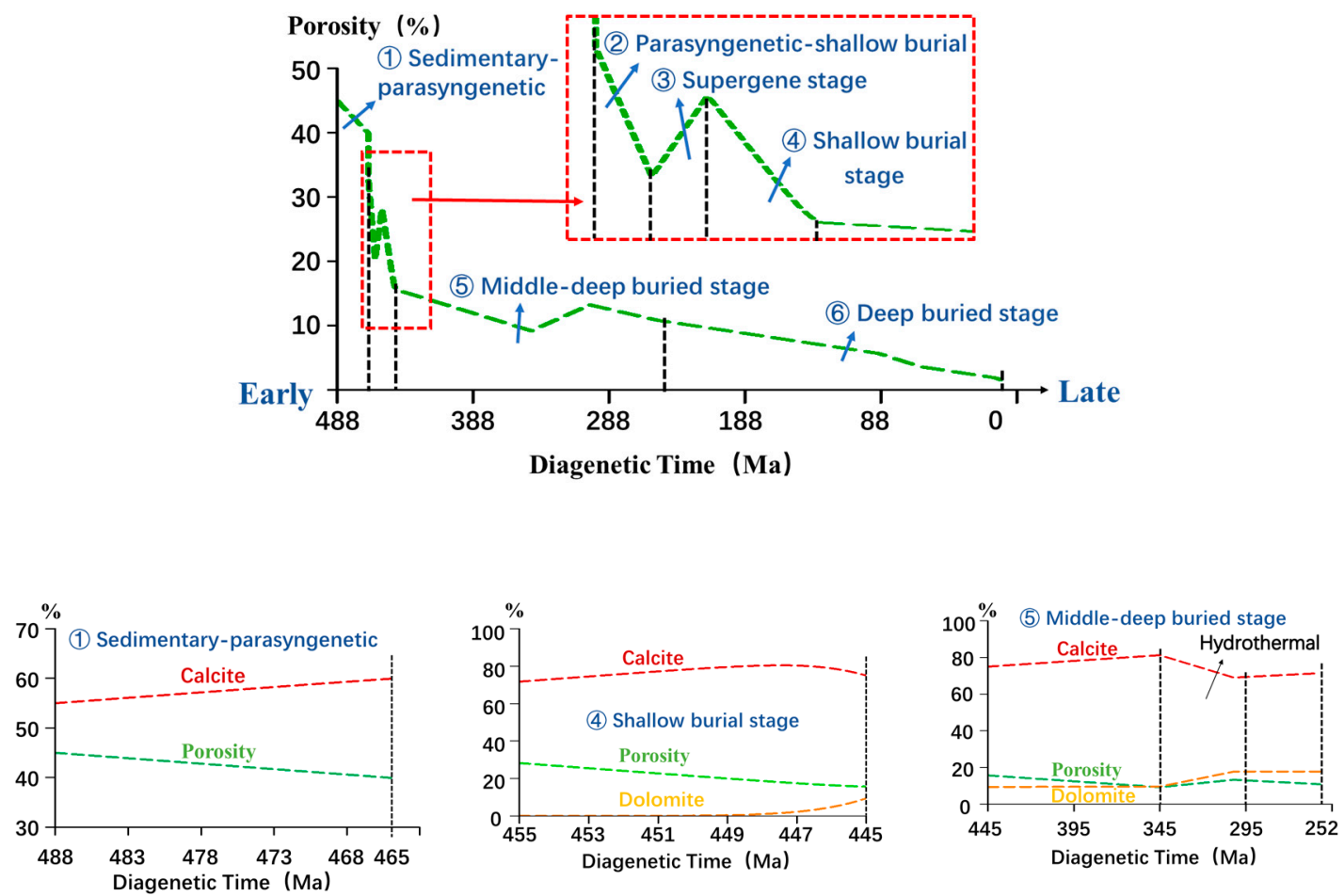

Figure 8. Porosity and typical mineral content evolution under marine phreatic environment.

\subsubsection{Meteoric Fresh Water and Freshwater Phreatic Environment in the Supralittoral Zone}

Porosity evolution under meteoric fresh water and freshwater phreatic environment is shown in Figure 9. With the synergistic effect of fresh water leaching, freshwater cementation and mechanical compaction, the porosity decreased to $38 \%$ during the sedimentary-parasyngenetic stage. As sea levels rose, the overlying seawater seeped into the stratum, and the porosity decreased to $22.2 \%$ in the parasyngenetic-shallow burial stage. During the supergene stage, dissolution occurred in the freshwater leaching environment, and the porosity increased to $33.9 \%$, while during the burial stage, calcite cementation and dolomitization made the porosity decrease to $14.5 \%$. As high salinity acidic hydrothermal fluid acted as diagenetic fluid, contributing to cementation, dissolution and dolomitization, porosity was almost constant throughout the middle-deep buried stage. Poor fluidity of formation water led to the weak cementation of calcite and the porosity reduced to $4.2 \%$ during the deep burial stage. 

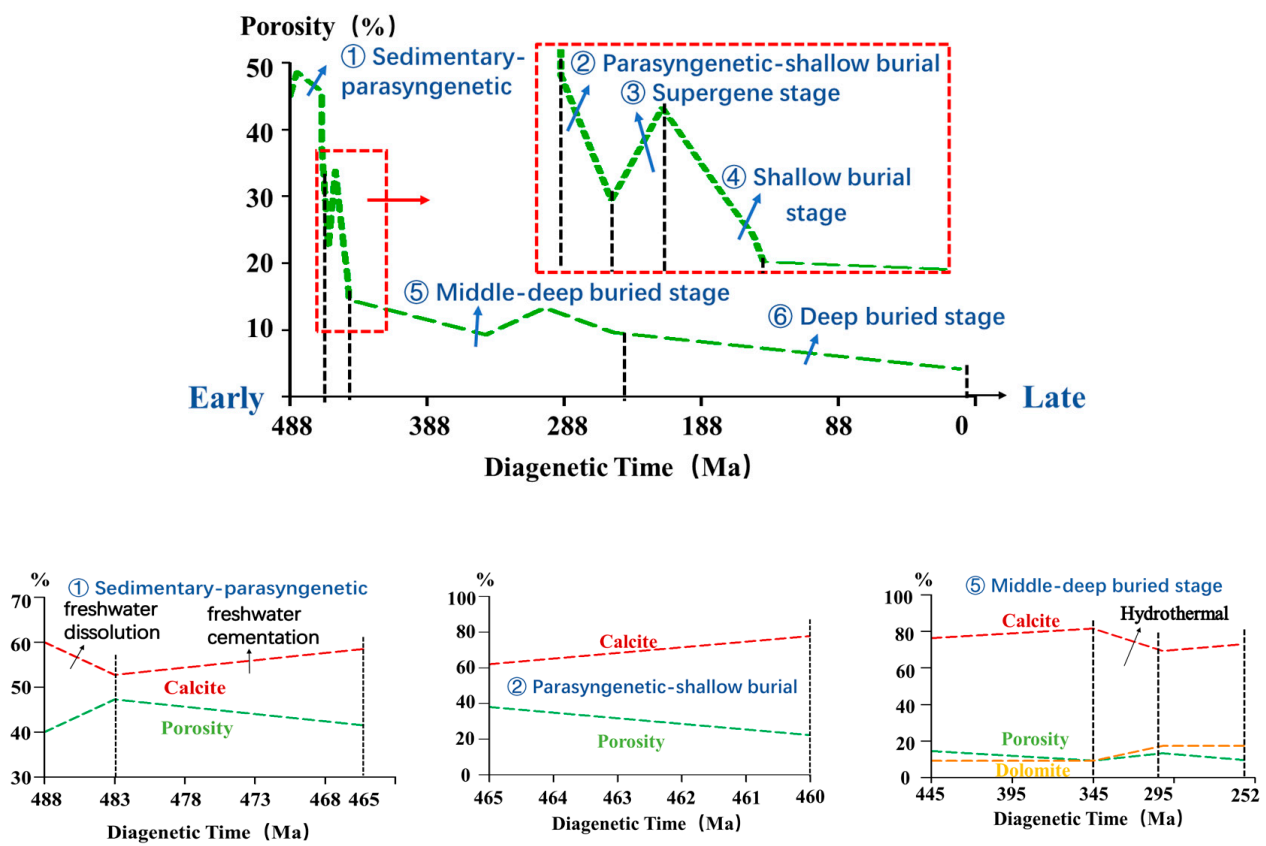

Figure 9. Porosity and typical mineral content evolution under meteoric fresh water and freshwater phreatic environment.

\subsubsection{Seawater Evaporation Environment in Shoal}

Porosity evolution under seawater evaporation environment is shown in Figure 10. During the sedimentary-parasyngenetic stage, cementation, dolomitization and mechanical compaction were the main reactions and porosity decreased to $36 \%$. In the parasyngenetic-shallow burial stage, poor fluidity of the infiltration fluid caused a large amount of calcite cement, resulting in a decrease in porosity. The porosity increased to $30.5 \%$ during the supergene stage. Due to calcite cementation and dolomitization, porosity decreased to $18.2 \%$ during the shallow burial stage. During the middle-deep buried stage, a large amount of calcite was converted into dolomite and a small amount of siliceous cement was formed, resulting in porosity decrease. Lastly, porosity decreased to $10.8 \%$ during the deep burial stage.
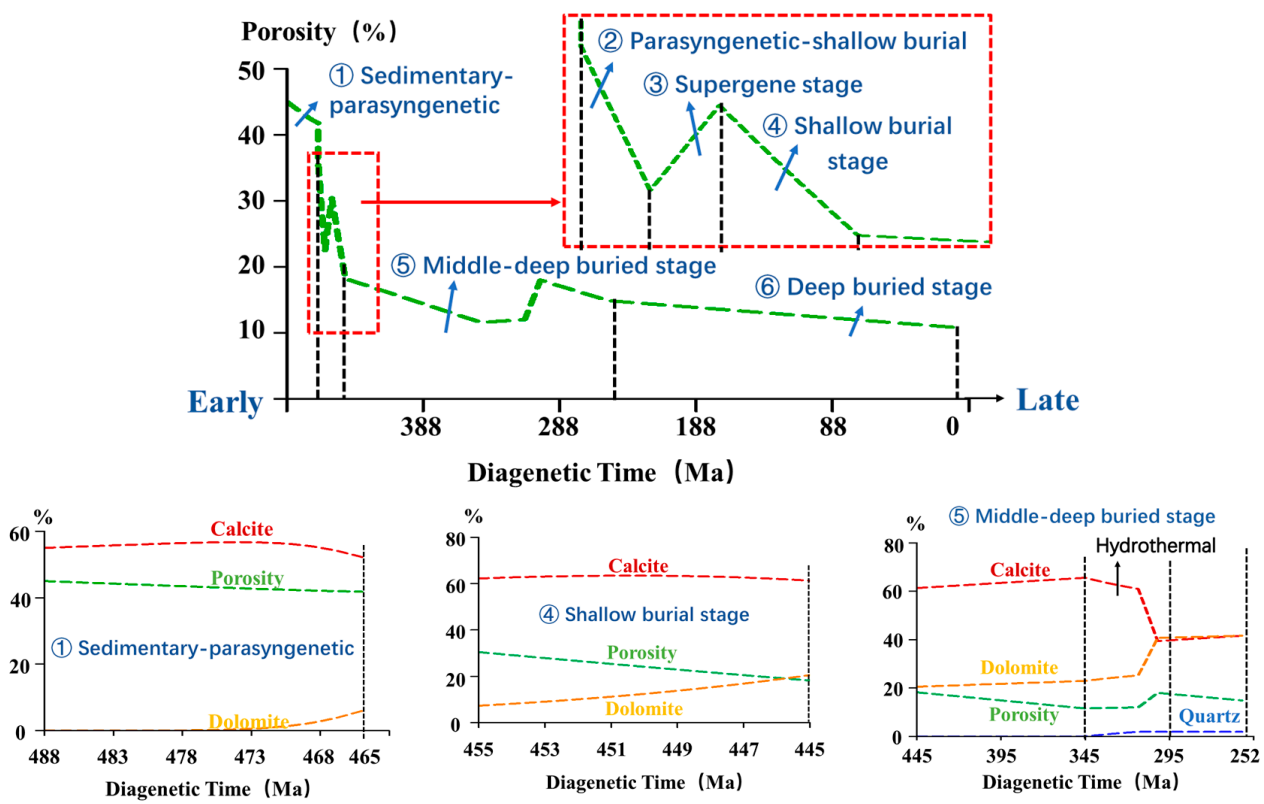

Figure 10. Porosity and typical mineral content evolution under seawater evaporation environment. 


\subsubsection{Seawater and Freshwater Interaction Environment in Intertidal Zones}

Porosity evolution under seawater and freshwater interaction environment is shown in Figure 11. Dissolution, cementation and mechanical compaction were the main diagenetic processes during the sedimentary-parasyngenetic stage, and the porosity decreased to 35\%. The porosity decreased to $19.7 \%$ because of calcite cement during the shallow burial stage and increased to $29 \%$ under the action of atmospheric freshwater leaching during the surface stage. In the shallow burial stage, the pore water gradually evolved into dolomitized fluid, causing calcite cementation and dolomitization and the porosity decreased to $13.9 \%$. During the middle-deep buried stage, acidic hydrothermal fluid with medium-low temperature, high salinity and rich $\mathrm{SiO}_{2}$ penetrated along the fault zone, and the porosity decreased to $9.3 \%$. However, the porosity increased to $19.0 \%$ after hydrothermal alteration. The poor fluidity of the formation water and low porosity-permeability resulted in a weak cementation and a porosity decrease of $17.1 \%$ during the deep burial stage.
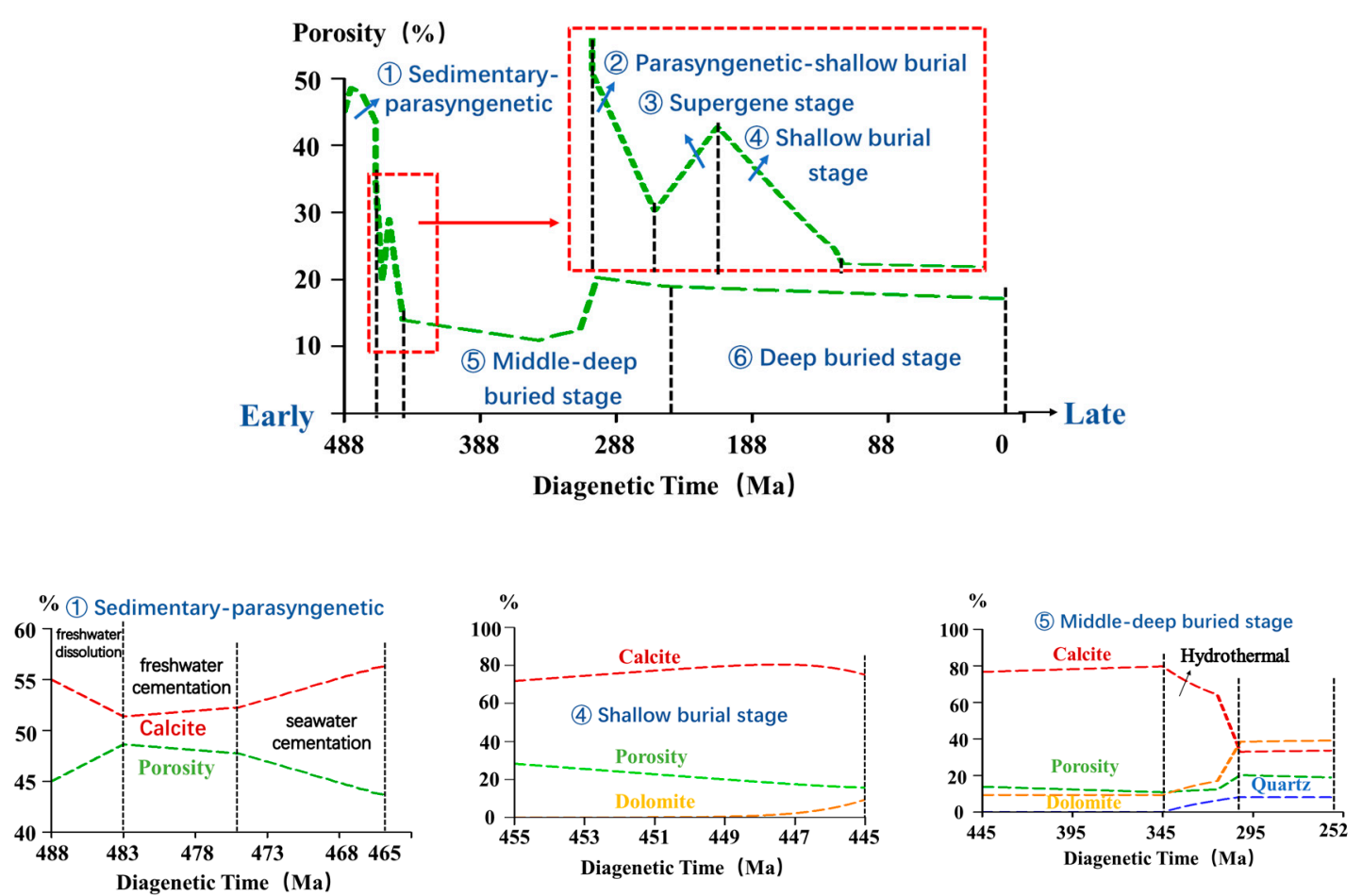

Figure 11. Porosity and typical mineral content evolution under seawater and freshwater interaction environment.

\section{Discussion}

\subsection{Effect of Geological Factors on Dolomitization}

The effect of the temperature, flow rate, fluid properties and other geological factors on dolomitization varied $[23,42,43]$. Results of one-dimensional models indicated that if the flow rate of the external fluid, i.e., the hydrodynamic condition, was different, the degree of dolomitization varied. The porosity change extent was consistent under various flow rate conditions, but different amounts of time were needed for the porosity to reach the same level. In short, the better the hydrodynamic conditions, the faster the fluid migration, which then pushed the reaction and expands the scope of dolomitization.

In two-dimensional models, comparing different groundwater surfaces, it was found that when the groundwater level was low, a $100 \mathrm{~m}$ unsaturated zone exist in the shallow layer, which contained much more gas. When external fluid entered the formation, it took a longer path to reach saturation, while more pores need to be filled in the meantime. Therefore, the reaction occurred later, and the 
degree of reaction was also weak due to the large number of ions being diluted during the porous flow process.

Different solution properties also lead to various levels of dolomitization $[13,43]$. The higher the $\mathrm{Mg} / \mathrm{Ca}$ ratio in the fluid, the better the precipitation of dolomite, due to the large amount of $\mathrm{Mg}$ needed in the dolomitization process. However, the $\mathrm{pH}$ value of the fluid only had a limited influence compared with other factors.

Dolomitization is a reaction that involves a volume decrease, i.e., the volume of minerals is reduced with the conversion of calcite to dolomite, so that the number of pores within the reservoir increases $[13,23]$. However, if a large amount of gypsum that can occupy some pores is formed in this process, then the porosity will decrease. The results of this study demonstrated that the amount and the degree of precipitation gypsum were various under different diagenetic temperatures, which led to a large disparity in reservoir porosity.

\subsection{Comparison of Model and Test Results during Successive Diagenetic Stages}

Diagenetic models' results were consistent with test data both in mineral transformation and porosity evolution. In models, calcite and dolomite contents increased and the porosity decreased from $45 \%$ to about $35 \%$ throughout the sedimentary-parasyngenetic stage (488-465 Ma), meanwhile, an observation also shows that the main diagenesis was carbonate cementation. It is worth noting that the porosity evolution varied under different sedimentary environments, which was determined by the complex fluid composition.

The depth ranges in the parasyngenetic-shallow burial stage (465-460 Ma) was 50-600 m. As sea levels rose, the overlying seawater seeped into the formation and replenished $\mathrm{Ca}^{2+}$ and $\mathrm{HCO}_{3}{ }^{-}$in the pore water. Both test and model results indicate that increased temperature and pressure with the burial depth was beneficial to calcite cementation.

During the supergene stage (460-455 Ma), deeply buried rocks were uplifted below the diving surface due to tectonic movements and underwent short-term erosion and weathering. With the leaching and dissolution of meteoric fresh water, fresh water with low ion concentration infiltrated into the formation, thus dissolving calcite, which led to the development of a large number of secondary pores.

During the shallow burial stage, porosity and mineral contents evolution show that the main diagenetic reactions were cementation and dolomitization, associated with a porosity decrease. As the burial depth increased, a gradual increase of formation temperature favored the overcoming of the dynamic obstacles to dolomite formation, which were dominant at the beginning of the shallow burial stage [44]. High-salinity concentrated seawater is the diagenetic fluid at this stage, which can easily flow downward under the effect of gravity and cause convection with low-density seawater at the bottom. Following the penetration of the high-salinity seawater in the stratum, calcite would begin to cement, causing the $\mathrm{Ca}^{2+}$ concentration in the fluid to decrease, and the $\mathrm{Mg}^{2+} / \mathrm{Ca}^{2+}$ to increase, which is beneficial for the fluid to overcome the kinetic obstacles. Calcite can then be replaced by dolomite, hence resulting in the decrease in calcite content with burial time. Previous studies have also shown that massive dolomitization of sediments is the main diagenesis in the shallow burial stage $[45,46]$.

During the middle-deep burial stage, the diagenetic fluids were medium-high salinity, $\mathrm{SiO}_{2}$-rich and $\mathrm{CO}_{2}$-rich deep hydrothermal fluids. $\mathrm{SiO}_{2}$ had a relatively high saturation in the hot liquid, whose temperature was about $200^{\circ} \mathrm{C}$ after entering the formation (the formation temperature was about 100 $\left.{ }^{\circ} \mathrm{C}\right)$. As the fluid flowed upward, reactions became different because of the different crack and fracture system in the formation. Strong hydrothermal dissolution happened in the fault zone of SN4 and SN5, with a developed fracture system.

During the deep burial stage (252-0 Ma), the temperature and pressure were high, which was conducive to the cementation and dolomitization. Calcite cementation occurred when high $\mathrm{Ca}^{2+}$ fluid entered the formation from the Lower Cambrian source rock, leading the content of calcite to increase 
and the porosity to decrease. With the high concentration of $\mathrm{Ca}^{2+}$, the $\mathrm{Mg} / \mathrm{Ca}$ continuously diminished, which is unfavorable for the dolomite precipitation.

\subsection{Implications for Reservoir Evolution under Various Sedimentary Environments}

The carbonate rock in the studied area experienced complex diagenesis under different sedimentary environments [43]. The various diagenetic phenomena observed were in the present results from the comprehensive effects of the sedimentary environments [47].

In the marine phreatic environment, cementation and compaction were the main diagenesis. As the carbonate deposits were all located below the sea level, the diagenetic fluid was seawater with a high concentration of $\mathrm{Ca}^{2+}$ and $\mathrm{Mg}^{2+}$, which favored the formation of calcium carbonate but not that of dolomite. A large number of thick ring-like cements and fibrous calcite cements could be seen in the thin slices of the SN6, which is a typical single well representative of sedimentary diagenesis in the seawater subsurface flow environment.

In the meteoric water and freshwater phreatic environment, dissolution, cementation and compaction were the main diagenesis. With the sea level decline, some carbonate sediments became exposed. Atmospheric fresh water leach causing calcite dissolution porosity increased. With continuous infiltration, the saturation increased and calcite cement was formed, leading the porosity to decrease. A large number of fenestrae secondary pores and few equiaxed-granular freshwater cements filling the slab hole could be seen in the thin slices of the SN7, which is a typical single well of sedimentary diagenesis in the meteoric fresh water and freshwater phreatic environment.

In the seawater evaporative environment, dolomitization and compaction were the main diagenesis. Under dry climatic conditions, strong evaporation caused seawater to concentrate. High salinity seawater flowed into the formation, resulting in an increase in the concentration of $\mathrm{Mg}^{2+}$ and $\mathrm{Ca}^{2+}$ in the pore water. This hypersaline water with a high concentration of $\mathrm{Mg}^{2+}$ increased the probability of effective collision between $\mathrm{Mg}^{2+}$ and $\mathrm{CO}_{3}{ }^{2-}$, increasing the dolomite content. SN3 and SN5 are typical wells of the sedimentary diagenesis in the seawater evaporation environment.

In the seawater and freshwater interaction environment, cementation, dissolution and compaction were the main diagenesis. Controlled by secondary sedimentary cycles and the sea level decline temporarily, carbonate deposits in the intertidal zone were exposed to the atmosphere. Afterwards, as the sea level rose, carbonate deposits were submerged again by seawater. A large number of intragranular and intergranular dissolved pores and casting pores were formed in SN4, and the pores were filled with equiaxed-granular freshwater cements and fibrous calcite seawater cements formed during the parasyngenetic stage.

\section{Conclusions}

A series of test analysis and numerical simulation were combined to study the effects of various factors (such as temperature, flow rate, seawater concentration, $\mathrm{Mg} / \mathrm{Ca}$ ratio, $\mathrm{pH}$ and $\mathrm{SO}_{4}{ }^{\mathrm{s}}$ concentration) on dolomitization during diagenesis in carbonate reservoirs. The degree of dolomitization varied with the flow rate and other hydrodynamic conditions of the external fluid. The better the hydrodynamic conditions, the faster the fluid migration, which then pushed the reaction and expanded the scope of dolomitization. Different solution properties and minerals also led to various levels of dolomitization. During successive diagenetic stages under different sedimentary environments with various temperatures, minerals, solutions and other conditions, reservoir experienced complicated fluid-rock reactions. The diagenetic process and porosity evolution curves in four different sedimentary environments were re-established in the studied area. The main controlling factors of dolomitization were identified, which is helpful to clarify the genesis and distribution of carbonate reservoirs. As the fluid-rock interaction mechanism in carbonate reservoirs is a complex process, further experimental and numerical simulation studies are planned to elaborate and enhance our understanding.

Author Contributions: Conceptualization, L.Y. (Leilei Yang) and K.L.; Methodology, L.Y. (Leilei Yang), and K.L.; Software, L.Y. (Leilei Yang); Validation, L.Y. (Linjiao Yu) and D.C.; Investigation, X.L.; Resources, P.Y.; 
Writing—original draft preparation, L.Y. (Leilei Yang); Writing—review and editing, L.Y. (Leilei Yang) and D.C.; Visualization, X.L.; Project administration, L.Y. (Leilei Yang); Funding acquisition, L.Y. (Leilei Yang) and K.L. All authors have read and agreed to the published version of the manuscript.

Funding: This research is supported by the Natural Science Foundation of China (No. 41702249) and the Strategic Priority Research Program of the Chinese Academy of Sciences, Grant No. XDA14010401. The data that support the findings of this study are available on request from the corresponding author. Please contact Leilei Yang, yangleilei@cup.edu.cn, for data used in this study.

Conflicts of Interest: The authors declare no conflicts of interest.

\section{References}

1. Alvarado, V.; Manrique, E. Enhanced Oil Recovery: An Update Review. Energies 2010, 3, $1529-1575$. [CrossRef]

2. Araujo, T.P.; Leite, M.G.P. Flow simulation with reactive transport applied to carbonate rock diagenesis. Mar. Pet. Geol. 2017, 88, 94-106. [CrossRef]

3. Ehrenberg, S.N.; Walderhaug, O.; Bjorlykke, K. Carbonate porosity creation by mesogenetic dissolution: Reality or illusion? AAPG Bull. 2012, 96, 217-233. [CrossRef]

4. Kang, Y. Reservoir rock characteristics of paleozoic marine facies carbonate rock in the Tarim Basin. Pet. Geol. Exp. 2007, 29, 217-223.

5. Rashid, F.; Glover, P.W.J.; Lorinczi, P.; Hussein, D.; Collier, R.; Lawrence, J. Permeability prediction in tight carbonate rocks using capillary pressure measurements. Mar. Pet. Geol. 2015, 68, 536-550. [CrossRef]

6. Teichert, B.M.A.; Johnson, J.E.; Solomon, E.A.; Giosan, L.; Rose, K.; Kocherla, M.; Connolly, E.C.; Torres, M.E. Composition and origin of authigenic carbonates in the Krishna-Godavari and Mahanadi Basins, eastern continental margin of India. Mar. Pet. Geol. 2014, 58, 438-460. [CrossRef]

7. Zou, C.; Zhu, R.; Liu, K.; Su, L.; Bai, B.; Zhang, X.; Yuan, X.; Wang, J. Tight gas sandstone reservoirs in China: Characteristics and recognition criteria. J. Pet. Sci. Eng. 2012, 88, 82-91. [CrossRef]

8. Javanbakht, M.; Wanas, H.A.; Jafarian, A.; Shahsavan, N.; Sahraeyan, M. Carbonate diagenesis in the Barremian-Aptian Tirgan Formation (Kopet-Dagh Basin, NE Iran): Petrographic, geochemical and reservoir quality constraints. J. Afr. Earth Sci. 2018, 144, 122-135. [CrossRef]

9. Ronchi, P.; Ortenzi, A.; Borromeo, O.; Claps, M.; Zempolich, W.G. Depositional setting and diagenetic processes and their impact on the reservoir quality in the late Visean-Bashkirian Kashagan carbonate platform (Pre-Caspian Basin, Kazakhstan). AAPG Bull. 2010, 94, 1313-1348. [CrossRef]

10. Yasuda, E.Y.; dos Santos, R.G.; Trevisan, O.V. Kinetics of carbonate dissolution and its effects on the porosity and permeability of consolidated porous media. J. Pet. Sci. Eng. 2013, 112, 284-289. [CrossRef]

11. Li, J.; Ma, Y.; Huang, K.; Zhang, Y.; Wang, W.; Liu, J.; Li, Z.; Lu, S. Quantitative characterization of organic acid generation, decarboxylation, and dissolution in a shale reservoir and the corresponding applications-A case study of the Bohai Bay Basin. Fuel 2018, 214, 538-545. [CrossRef]

12. Li, Y.; Yang, W.; Wang, Q.; Song, Y.; Jiang, Z.; Guo, L.; Zhang, Y.; Wang, J. Influence of the actively migrated diagenetic elements on the hydrocarbon generation potential in tuffaceous shale. Fuel 2019, 256, 115795. [CrossRef]

13. Read, J.F.; Husinec, A.; Cangialosi, M.; Loehn, C.W.; Prtoljan, B. Climate controlled, fabric destructive, reflux dolomitization and stabilization via marine- and synorogenic mixed fluids: An example from a large Mesozoic, calcite-sea platform, Croatia. Palaeogeogr. Palaeoclimatol. Palaeoecol. 2016, 449, 108-126. [CrossRef]

14. Zhao, H.; Ning, Z.; Zhao, T.; Zhang, R.; Wang, Q. Effects of mineralogy on petrophysical properties and permeability estimation of the Upper Triassic Yanchang tight oil sandstones in Ordos Basin, Northern China. Fuel 2016, 186, 328-338. [CrossRef]

15. Miller, K.; Vanorio, T.; Keehm, Y. Evolution of permeability and microstructure of tight carbonates due to numerical simulation of calcite dissolution. J. Geophys. Res. Solid Earth 2017, 122, 4460-4474. [CrossRef]

16. Pearce, J.K.; Golab, A.; Dawson, G.K.W.; Knuefing, L.; Goodwin, C.; Golding, S.D. Mineralogical controls on porosity and water chemistry during $\mathrm{O}_{2}-\mathrm{SO}_{2}-\mathrm{CO}_{2}$ reaction of $\mathrm{CO}_{2}$ storage reservoir and cap-rock core. Appl. Geochem. 2016, 75, 152-168. [CrossRef]

17. Adams, A.; Diamond, L.W. Early diagenesis driven by widespread meteoric infiltration of a Central European carbonate ramp: A reinterpretation of the Upper Muschelkalk. Sediment. Geol. 2017, 362, 37-52. [CrossRef] 
18. Berkowitz, B.; Singurindy, O.; Lowell, R.P. Mixing-driven diagenesis and mineral deposition: $\mathrm{CaCO}_{3}$ precipitation in salt water-fresh water mixing zones. Geophys. Res. Lett. 2003, 30, 4. [CrossRef]

19. Dumariska-Slowik, M.; Powolny, T.; Sikorska-Jaworowska, M.; Heflik, W.; Morgun, V.; Xuan, B.T. Mineralogical and geochemical constraints on the origin and evolution of albitites from Dmytrivka at the Oktiabrski complex, Southeast Ukraine. Lithos 2019, 334, 231-244. [CrossRef]

20. Jones, G.D.; Xiao, Y.T. Geothermal convection in the Tengiz carbonate platform, Kazakhstan: Reactive transport models of diagenesis and reservoir quality. AAPG Bull. 2006, 90, 1251-1272. [CrossRef]

21. Jons, N.; Kahl, W.A.; Bach, W. Reaction-induced porosity and onset of low-temperature carbonation in abyssal peridotites: Insights from 3D high-resolution microtomography. Lithos 2017, 268, 274-284. [CrossRef]

22. Putnis, A.; Hinrichs, R.; Putnis, C.V.; Golla-Schindler, U.; Collins, L.G. Hematite in porous red-clouded feldspars: Evidence of large-scale crustal fluid-rock interaction. Lithos 2007, 95, 10-18. [CrossRef]

23. Iannace, A.; Capuano, M.; Galluccio, L. "Dolomites and dolomites" in Mesozoic platform carbonates of the Southern Apennines: Geometric distribution, petrography and geochemistry. Palaeogeogr. Palaeoclimatol. Palaeoecol. 2011, 310, 324-339. [CrossRef]

24. Li, Q.; Zhang, Y.; Dong, L.; Guo, Z. Oligocene syndepositional lacustrine dolomite: A study from the southern Junggar Basin, NW China. Palaeogeogr. Palaeoclimatol. Palaeoecol. 2018, 503, 69-80. [CrossRef]

25. Tosti, F.; Mastandrea, A.; Guido, A.; Demasi, F.; Russo, F.; Riding, R. Biogeochemical and redox record of mid-late Triassic reef evolution in the Italian Dolomites. Palaeogeogr. Palaeoclimatol. Palaeoecol. 2014, 399, 52-66. [CrossRef]

26. Ebrahimi, P.; Vilcaez, J. Effect of brine salinity and guar gum on the transport of barium through dolomite rocks: Implications for unconventional oil and gas wastewater disposal. J. Environ. Manag. 2018, 214, 370-378. [CrossRef]

27. Giorgioni, M.; Iannace, A.; D’Amore, M.; Dati, F.; Galluccio, L.; Guerriero, V.; Mazzoli, S.; Parente, M.; Strauss, C.; Vitale, S. Impact of early dolomitization on multi-scale petrophysical heterogeneities and fracture intensity of low-porosity platform carbonates (Albian-Cenomanian, southern Apennines, Italy). Mar. Pet. Geol. 2016, 73, 462-478. [CrossRef]

28. Huang, S.; Gong, Y.; Huang, K.; Tong, H. The Influence of Burial History on Carbonate Dissolution and Precipitation A Case Study from Feixianguan Formation of Triassic, NE Sichuan and Ordovician Carbonate of Northern Tarim Basin. Adv. Earth Sci. 2010, 25, 381-390.

29. Vincent, B.; Waters, J.; Witkowski, F.; Daniau, G.; Oxtoby, N.; Crowley, S.; Ellam, R. Diagenesis of Rotliegend sandstone reservoirs (offshore Netherlands): The origin and impact of dolomite cements. Sediment. Geol. 2018, 373, 272-291. [CrossRef]

30. Jasionowski, M.; Peryt, T.M.; Durakiewicz, T. Polyphase dolomitisation of the Wuchiapingian Zechstein Limestone (Ca1) isolated reefs (Wolsztyn Palaeo-Ridge, Fore-Sudetic Monocline, SW Poland). Geol. Q. 2014, 58, 493-510.

31. Chen, X.; Yi, W.; Lu, W. The Paleokarst Reservoirs of Oil/Gas Flelds in China. Acta Sedimentol. Sin. 2004, 22, 244-253.

32. Ni, X.; Zhang, L.; Shen, A.; Qiao, Z.; Han, L. Diagenesis and pore evolution of the Ordovician karst reservoir in Yengimahalla-Hanilcatame region of Tarim Basin. J. Palaeogeogr. 2010, 12, 467-479.

33. Wang, T.; Song, D.; Li, M.; Yang, C.; Ni, Z. Natural gas source and deep gas exploration potential of the Ordovician Yingshan Formation in the Shunnan-Gucheng region, Tarim Basin. Oil Gas Geol. 2014, 35, 753-762.

34. Yu, Z.; Liu, K.; Zhao, M.; Liu, S.; Zhuo, Q.; Lu, X. Characterization of Diagenesis and the Petroleum Charge in Kela 2 Gas Field, Kuqa Depression, Tarim Basin. Earth Sci. 2016, 41, 533-545.

35. Jiao, C.; He, Z.; Xing, X.; Qing, H.; He, B.; Li, C. Tectonic hydrothermal dolomite and its significance of reservoirs in Tarim basin. Acta Pet. Sin. 2011, 27, 277-284.

36. You, D.; Han, J.; Hu, W.; Qian, Y.; Cao, Z.; Chen, Q.; Li, H. Characteristics and genesis of pores and micro-pores in ultra-deep limestones: A case study of Yijianfang Formation limestones from Shunnan-7 and Shuntuo-1 wells in Tarim Basin. Oil Gas Geol. 2017, 38, 693-702.

37. Li, Z.; Li, J.; Zhang, P.; Yu, J.; Liu, J.; Yang, L. Key Structural-Fluid Evolution and Reservoir Diagenesis of Deep-buried Carbonates: An Example from the Ordovician Yingshan Formation in Tazhong, Tarim Basin. Bull. Mineral. Petrol. Geochem. 2016, 35, 827-838. 
38. Lu, Z.; Chen, H.; Qing, H.; Chi, G.; You, D.; Hang, Y.; Zhang, S. Petrography, fluid inclusion and isotope studies in Ordovician carbonate reservoirs in the Shunnan area, Tarim basin, NW China: Implications for the nature and timing of silicification. Sediment. Geol. 2017, 359, 29-43. [CrossRef]

39. Liu, W.; Huang, Q.; Wang, K.; Shi, S.; Jiang, H. Characteristics of hydrothermal activity in the Tarim Basin and its reworking effect on carbonate reservoirs. Nat. Gas Ind. 2016, 36, 14-21. [CrossRef]

40. Xu, T.; Sonnenthal, E.; Spycher, N.; Pruess, K. TOUGHREACT-A simulation program for non-isothermal multiphase reactive geochemical transport in variably saturated geologic media: Applications to geothermal injectivity and $\mathrm{CO}_{2}$ geological sequestration. Comput. Geosci. 2006, 32, 145-165. [CrossRef]

41. Ma, J.; Li, C.; Li, B. Distribution and changes of current, temperature and salinity in the equatorial region of the western Pacific Ocean. Acta Oceanol. Sin. 1985, 7, 131-142.

42. Helpa, V.; Rybacki, E.; Abart, R.; Morales, L.F.G.; Rhede, D.; Jeřábek, P.; Dresen, G. Reaction kinetics of dolomite rim growth. Contrib. Mineral. Petrol. 2014, 167, 1001. [CrossRef]

43. Montes-Hernandez, G.; Findling, N.; Renard, F. Dissolution-precipitation reactions controlling fast formation of dolomite under hydrothermal conditions. Appl. Geochem. 2016, 73, 169-177. [CrossRef]

44. Machel, H.G. Concepts and models of dolomitization: A critical reappraisal. Geol. Soc. Lond. Spec. Publ. 2004, 235, 7-63. [CrossRef]

45. Huang, Q.; Liu, D.; Ye, N.; Li, Y. Reservoir characteristics and diagenesis of the Cambrian dolomite in the Tarim Basin. J. Northeast Pet. Univ. 2013, 37, 63-74.

46. Li, P.; Chen, G.; Zeng, Q.; Yi, J.; Hu, G. Genesis of Lower Ordovician Dolomite in Central Tarim Basin. Acta Sedimentol. Sin. 2011, 29, 842-856.

47. Hu, M.; Hu, Z.; Li, S.; Wang, Y. Geochemical Characteristics and Genetic Mechanism of the Ordovician Dolostone in the Tazhong Area, Tarim Basin. Acta Geol. Sin. 2011, 85, 2060-2069.

(C) 2020 by the authors. Licensee MDPI, Basel, Switzerland. This article is an open access article distributed under the terms and conditions of the Creative Commons Attribution (CC BY) license (http://creativecommons.org/licenses/by/4.0/). 